\title{
Variability in clinical prevalence of PaV1 in Caribbean spiny lobsters occupying commercial casitas over a large bay in Mexico
}

\author{
Rebeca I. Candia-Zulbarán, Patricia Briones-Fourzán*, Fernando Negrete-Soto, \\ Cecilia Barradas-Ortiz, Enrique Lozano-Álvarez
}

Unidad Académica de Sistemas Arrecifales, Instituto de Ciencias del Mar y Limnología,

Universidad Nacional Autónoma de México, Prol. Av. Niños Héroes s/n, Puerto Morelos, Quintana Roo, 77580 Mexico

\begin{abstract}
In Bahía de la Ascensión, Mexico, the fishery for spiny lobsters Panulirus argus is based on the extensive use of casitas, large artificial shelters that can harbor the full size range of these highly gregarious lobsters. The discovery of a pathogenic virus in these lobsters (Panulirus argus virus 1, or PaV1) has raised concern about its potential effects on casita-based fisheries. Because in Bahía de la Ascensión visibly infected lobsters represent an immediate loss of revenue, we examined variability in clinical prevalence of PaV1 (percentage of lobsters visibly infected) in thousands of lobsters sampled from the commercial catch at the onset of 3 consecutive fishing years, and from 530 casitas distributed over 3 zones within the bay during 2 fishing and 2 closed seasons. In the commercial catch (lobsters 67 to $147 \mathrm{~mm}$ carapace length [CL]), clinical prevalence of PaV1 was low and was not affected by year or sex. In lobsters (9.2 to $115.0 \mathrm{~mm} \mathrm{CL}$ ) that occupied casitas, clinical prevalence of PaV1 varied with sampling season and was always higher in juveniles than in subadults or adults, but was consistently lower in one zone relative to the other 2 zones. The average clinical prevalence of $\mathrm{PaV} 1$ in this bay was statistically similar to the average clinical prevalence reported in Cuba, where casitas are also used, and in Florida Bay, USA, where casitas are not used. To date, PaV1 has had no discernible impact on the lobster fishery in Bahía de la Ascensión, suggesting that clinical prevalence is not influenced by the use of casitas per se.
\end{abstract}

KEY WORDS: Panulirus argus virus $1 \cdot \mathrm{PaV} 1 \cdot$ Artificial shelters $\cdot$ Casitas $\cdot$ Clinical prevalence Bahía de la Ascensión · Mexico

\section{INTRODUCTION}

Spiny lobsters (Palinuridae) represent valuable fisheries resources in all tropical and temperate seas of the world, and the Caribbean spiny lobster Panulirus argus (Latreille, 1804) constitutes nearly $50 \%$ of the world catch (Phillips \& Melville-Smith 2006). Throughout the Caribbean region, fishers use a vast array of fishing methods to catch $P$. argus. In particular, in certain areas of Cuba and the Bahamas, and in 2 bays located on the Caribbean coast of Mexico
(Bahía de la Ascensión and Bahía Espíritu Santo), large artificial shelters called 'casitas' are extensively used to commercially harvest lobsters (BrionesFourzán et al. 2000, Cruz \& Phillips 2000, Ehrhardt et al. 2010). Basically, a casita is a flat slab separated from the substrate by a few centimeters, thus creating a large 'crevice' that can harbor multiple lobsters (Briones-Fourzán et al. 2000).

With the exception of the smallest benthic juveniles, Panulirus argus show a strong tendency to aggregate in diurnal crevice-type shelters (Childress 
\& Herrnkind 1996). Gregariousness increases survival of $P$. argus because shelter-sharing lobsters use their long and spiny antennae in concert to fend off approaching predators (Herrnkind et al. 2001), and lobsters seeking shelter reduce their time of exposure by following chemical cues released from sheltered conspecifics (Ratchford \& Eggleston 1998, Nevitt et al. 2000, Childress \& Herrnkind 2001). Thus, by promoting gregariousness and hence survival, casitas increase local density and biomass of $P$. argus lobsters (Briones-Fourzán \& Lozano-Álvarez 2001, Briones-Fourzán et al. 2007).

However, wild populations of Panulirus argus are currently affected by a pathogenic disease caused by an unclassified virus named Panulirus argus virus 1 (PaV1) (Shields \& Behringer 2004). The pathology of lobsters infected with PaV1 was recently reviewed by Shields (2011) and Behringer et al. (2011). Briefly, upon infecting a host, PaV1 attacks circulating hyalinocytes and semigranulocytes. The virus also targets the spongy connective tissue, and the hepatopancreas is the most severely affected organ. Heavily infected lobsters eventually die from metabolic wasting. Clinical (i.e. visible or macroscopic) signs of infection (indicating the presence of disease) are a milky white hemolymph that fails to clot (as opposed to the normal transparent, bluish hemolymph that clots rapidly) and a reddish discoloration over the exoskeleton. As infection progresses, lobsters become lethargic and cease to molt, as indicated by their fouled carapaces. PaV1 primarily infects benthic juvenile lobsters, and prevalence decreases with increasing size of lobsters.

The discovery that PaV1 can be transmitted by contact and over short distances through water (Butler et al. 2008) has raised concern about the potential impact of this viral disease on the fisheries for Panulirus argus, especially where casitas are used (Behringer et al. 2012). On the other hand, grossly normal lobsters tend to avoid shelters harboring diseased conspecifics, potentially limiting the spread of the virus (Behringer et al. 2006). However, this avoidance behavior may be modulated by the local availability of appropriate shelter. For example, Lozano-Álvarez et al. (2008) recorded high levels of cohabitation between grossly normal lobsters and lobsters visibly infected with PaV1 in casitas, suggesting that lobsters may make a trade-off between avoiding disease and avoiding predation.

In wild populations affected by a pathogenic disease, some hosts are likely to be uninfected, some subclinically infected (i.e. infected but not diseased) and others clinically infected (i.e. diseased); there- fore, surveys based only on clinical prevalence underestimate the true prevalence of infection (Flegel 2007, Behringer et al. 2011, Flegel \& Sritunyalucksana 2011). Estimating the true prevalence of PaV1 requires the use of expensive and/or time-consuming techniques such as histopathological analyses (Shields \& Behringer 2004), fluorescence in situ hybridization (Li et al. 2006), or PCR assays (Montgomery-Fullerton et al. 2007). These techniques have invariably confirmed the presence of PaV1 in wild Panulirus argus that have exhibited milky white hemolymph (Huchin-Mian et al. 2008, Cruz-Quintana et al. 2011, Pascual-Jiménez et al. 2012, this Special), but have also revealed that many lobsters that appear grossly normal are subclinically infected (e.g. Behringer et al. 2012, J. P. Huchin-Mian unpubl. data). However, from a fisheries perspective, estimating clinical prevalence of PaV1 may provide useful information. For example, in Bahía de la Ascensión, legal-sized lobsters clinically infected with PaV1 are not commercialized and hence represent a loss of revenue, while clinically infected juvenile lobsters, which are more likely to succumb to the disease, may represent a more immediate source of mortality for the population. Therefore, the aim of the present study was to assess spatial and temporal variations in clinical prevalence of PaV1 in lobsters from Bahía de la Ascensión to provide insight into the potential impact of this pathogenic disease on casita-based fisheries.

\section{MATERIALS AND METHODS}

\section{Study area}

Bahía de la Ascensión is a large, shallow bay (740 km² in area, average depth $3.5 \mathrm{~m}$, maximum depth $7 \mathrm{~m}$ ) located on the Caribbean coast of Mexico (state of Quintana Roo). The bay is protected from wave surge by an interrupted subtidal coral reef (Jordán-Dahlgren et al. 1994) (Fig. 1). It is bordered by coastal mangrove forests, and there is a chain of mangrove keys ('cayos') emerging near the center of the bay (Fig. 1). Depth increases rapidly at a distance of 1 to $3 \mathrm{~km}$ off the coast (Lozano-Álvarez et al. 1993). A complex patch mosaic of benthic habitats occurs across the bay, but in general, the outermost third of the bay is dominated by extensive seagrass-macroalgal meadows that offer a good settlement habitat for postlarvae of Panulirus argus. The middle third of the bay contains less vegetation and more exposed hard bottoms. The innermost third is characterized by a 


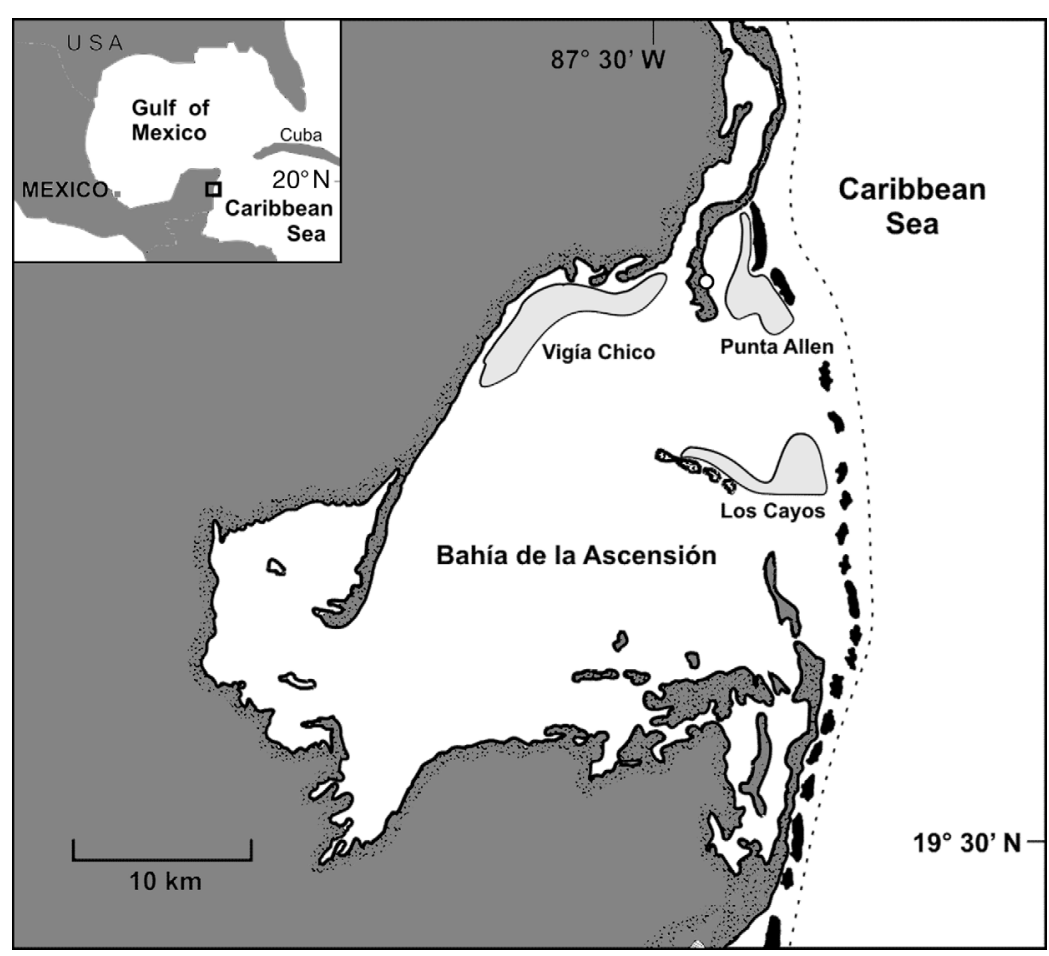

Fig. 1. Approximate locations of the 3 zones (light gray areas) where lobsters were sampled directly from casitas in Bahía de la Ascensión. The series of black patches off the mouth of the bay denote the location of the coral reef, and the broken line represents the $100 \mathrm{~m}$ isobath. (o): Location of the fishing

village. Inset shows the location of Bahía de la Ascensión (ㅁ) in Mexico the casitas by skin diving and extract the lobsters with hand nets. Internal regulations of the cooperative forbid fishing in someone else's campo (to ensure ownership of casitas), the use of SCUBA or hookah diving and the use of gaffs as fishing gear. Federal fishing regulations include a minimum legal size of $135 \mathrm{~mm}$ abdominal length $(\sim 74 \mathrm{~mm}$ carapace length [CL] on average), a 4 mo closed season from March 1 to June 30 and a prohibition on capturing ovigerous females.

\section{Data collection}

We sampled lobsters from (1) the commercial catch, which consists of adult and large subadult lobsters and (2) directly from hundreds of casitas harboring the full size range of lobsters, from small juveniles to adults. Lobsters from the commercial catch were randomly sampled at the landing site (the town pier) at the onset of 3 fishing seasons (July to August in 2008, 2009 and 2010), when the catch is typically highest (Lozano-Álvarez thick layer of soft, unconsolidated sediments overlaying the limestone bottom (Lozano-Álvarez et al. 1991, Briones-Fourzán 1994, Arellano-Méndez et al. 2011). Along the entire margin of the bay there is only one small village (population 600) officially named 'Javier Rojo Gómez', but also known as 'Punta Allen' after the land point where it is located (Fig. 1).

\section{The lobster fishery in Bahía de la Ascensión}

The Panulirus argus fishery in Bahía de la Ascensión is remarkably sustainable owing to the organizational scheme implemented by the fishing cooperative that includes all the local fishers (Sosa-Cordero et al. 2008). Briefly, the bottom of the bay was partitioned into numerous fishing parcels ('campos') allotted to individual fishers. Fishers are free to deploy within their campos as many casitas as they are willing to invest in, but on average, there are 3.3 casitas $\mathrm{ha}^{-1}$ in individual campos. Most casitas are made entirely of ferrocement and measure $\sim 2 \mathrm{~m}^{2}$ in surface area and $\sim 12 \mathrm{~cm}$ in inner height. The fishers survey et al. 1991). Lobsters were individually measured (mm CL) with vernier calipers $( \pm 0.1 \mathrm{~mm})$, sexed (based on dimorphic characters), and externally inspected for clinical signs of PaV1 infection (milky white hemolymph, clearly visible through the transparent membrane between the cephalothorax and the abdomen, combined or not with a reddish discoloration over the exoskeleton).

We sampled lobsters directly from casitas during 2 fishing seasons (FS) and 2 closed seasons (CS). However, as the cooperative requested that sampling not be conducted during the first months of the FS (July to October) and the last month of the CS (June), we took samples in November 2008 to February 2009 (FS1), May 2009 (CS1), December 2009 to February 2010 (FS2) and April 2010 (CS2). In all 4 seasons we sampled lobsters from numerous casitas distributed over 2 large bay zones: 'Punta Allen', which comprised multiple campos located between Punta Allen and the coral reef, and 'Vigía Chico', which comprised multiple campos along the northern coast in the middle third of the bay (Fig. 1). In CS1 and CS2 we also sampled lobsters from numerous casitas in 
another bay zone, 'Los Cayos', which comprised multiple campos along the chain of mangrove keys and extended towards the coral reef (Fig. 1).

Sampling operations were conducted by 2 teams in separate boats. Starting in different parts of a zone, each team sailed along transects roughly perpendicular to the nearest coast and surveyed all casitas encountered en route by skin diving. All lobsters found in a given casita were extracted with hand nets and placed into a large mesh bag, which was then secured to one side of the boat so that the lobsters were kept underwater (Lozano-Álvarez et al. 1991). To further minimize exposure to air, lobsters were extracted from the bag one at a time, measured with vernier calipers ( $\mathrm{mm} \mathrm{CL}$ ), inspected for clinical signs of PaV1 infection and immediately returned to the same casita. The entire procedure took less than 2 min per lobster. At all times, inspection of lobsters was done by the same 2 persons (1 per team). These 2 persons have inspected thousands of lobsters for clinical signs of infection by PaV1 since 2000. In 2008 , their accuracy in correctly identifying clinically infected lobsters $(100 \%)$ was tested in the laboratory by PCR assays.

\section{Statistical analyses}

The data were subjected to logistic regression analyses in which the binary response variable was the presence or absence of clinical signs of PaV1 infection. For lobsters sampled from the commercial catch, we were interested in testing the effects of size (continuous covariate) and the following categorical factors on the probability of finding clinically infected lobsters: year (to examine temporal variability in clinical prevalence of PaV1), sex (to examine whether in large lobsters, which are typically less susceptible to PaV1, both sexes were equally likely to manifest the disease) and ontogenetic phase (to compare clinical prevalence between the 2 ontogenetic phases that comprise the catch: subadults $[\leq 80 \mathrm{~mm} \mathrm{CL}]$ and adults [>80 $\mathrm{mm} \mathrm{CL}]$ )

For lobsters sampled directly from casitas, we were interested in examining the effects of size (continuous covariate) and the following categorical factors on the probability of finding clinically infected lobsters: sampling season and zone (to examine temporal and spatial variability in clinical prevalence) and ontogenetic phase (to compare levels of clinical prevalence among small juveniles $[<30 \mathrm{~mm} \mathrm{CL}]$, large juveniles [ 30.1 to $50 \mathrm{~mm} \mathrm{CL}$ ], subadults [50.1 to $80 \mathrm{~mm} \mathrm{CL}$ ] and adults [ $>80 \mathrm{~mm} \mathrm{CL}]$ ).

Finally, owing to the different provenance of subadult and adult lobsters sampled from the commercial catch (obtained from casitas distributed throughout Bahía de la Ascensión) and those that we sampled directly from casitas (restricted to our 3 sampling zones), we compared the clinical prevalence of PaV1 in lobsters of these ontogenetic phases sampled from both sources. In all cases, 2-sided 95\% CIs for prevalence were computed using Wilson's score method with continuity correction (see Newcombe 1998). Results of all statistical analyses were considered significant if $\mathrm{p}<0.05$.

\section{RESULTS}

\section{Samples from the commercial catch}

Overall, we examined 5132 lobsters (67.0 to $147.3 \mathrm{~mm} \mathrm{CL})$ from the commercial catch. The clinical prevalence of $\mathrm{PaV} 1$ (percent of lobsters visibly infected $\pm 95 \% \mathrm{CI}$ ) in different categories of these lobsters is shown in Table 1. Relative to 2008, we substantially increased sample sizes in 2009 and 2010 to obtain a more precise estimation of prevalence (Newcombe 1998). Yearly estimates of clinical prevalence of PaV1 in lobsters from the commercial catch varied between 0.7 and $1.6 \%$ (average: $1.1 \%$ ) (Table 1 ). The paucity of clinically

Table 1. Panulirus argus. Numbers of spiny lobsters sampled from the commercial catch in Bahía de la Ascensión (size range: 67.0 to $147.3 \mathrm{~mm}$ carapace length, CL) and estimates of clinical prevalence of Panulirus argus virus 1 (PaV1; percent of lobsters visibly infected) by year, sex and ontogenetic phase (subadults: $\leq 80 \mathrm{~mm} \mathrm{CL}$; adults: $>80 \mathrm{~mm} \mathrm{CL}$ )

\begin{tabular}{|lcccc|}
\hline Category & $\begin{array}{c}\text { Visibly } \\
\text { infected }\end{array}$ & $\begin{array}{c}\text { Grossly } \\
\text { normal }\end{array}$ & Total & $\begin{array}{c}\text { Clinical prevalence } \\
(\%) \text { of PaV1 }(95 \% \text { CI })\end{array}$ \\
\hline Year & & & & \\
2008 & 4 & 367 & 371 & $1.1(0.4-2.9)$ \\
2009 & 30 & 1905 & 1935 & $1.6(1.1-2.2)$ \\
2010 & 21 & 2805 & 2826 & $0.7(0.5-1.2)$ \\
Sex & & & & \\
Female & 23 & 2386 & 2409 & $1.0(0.6-1.5)$ \\
Male & 32 & 2691 & 2723 & $1.2(0.8-1.7)$ \\
$\begin{array}{l}\text { Ontogenetic phase } \\
\text { Subadults }\end{array}$ & 41 & 1988 & 2029 & $2.0(1.5-2.8)$ \\
Adults & 14 & 3089 & 3103 & $0.5(0.3-0.8)$ \\
\hline
\end{tabular}


infected lobsters impeded subjecting the data to a full logistic regression model; therefore, we first tested the effects of size, year and sex (Model A) and then tested the effects of year and ontogenetic phase (Model B) on the probability of finding clinically infected lobsters. Estimates for Model A revealed that this probability significantly decreased as lobster size increased but was not significantly affected by year or sex (Table 2), or their interactions (p-values: 0.201 to 0.278). Estimates for Model B showed that the probability of finding clinically infected lobsters was significantly higher in subadults relative to adults (odds ratio: 2.33) and marginally higher in 2009 relative to 2010 (odds ratio: 1.68) (Table 2). The lack of significant interactions (p-values: 0.510 to 0.958 ) reflected that, in all $3 \mathrm{yr}$, clinical prevalence of PaV1 was higher in subadults (range: 1.5 to $3.0 \%$, average: $2.2 \%$ ) than in adults (range: 0.2 to $0.8 \%$, average: $0.45 \%$ ) (Fig. 2).

\section{Samples from casitas}

We surveyed a total of 530 casitas harboring 4849 lobsters (9.2 to $115.0 \mathrm{~mm} \mathrm{CL})$. Overall, most lobsters found in casitas were subadults (53.1\%) and large juveniles (32.0\%), and there was a lower proportion of small juveniles (9.3\%) and adults $(5.6 \%)$; clinical prevalence of PaV1 decreased within successive ontogenetic phases (Table 3). In the full size range of lobsters, seasonality in clinical prevalence of PaV1 varied from 4.1 to $6.0 \%$ (average: $4.8 \%$ ). It was not possible to subject the entire data set to a full regression analysis because (1) Los Cayos was only sampled in 2 sampling seasons, (2) we found no clinically infected adults in any of the casitas that we sampled (Table 3) and (3) in some sampling seasons, we also found no clinically infected lobsters within other ontogenetic phases in Vigía Chico (data not shown). Therefore, we did 3 separate analyses to test the effect of different factors on the probability of finding clinically infected lobsters. In Model A, we tested the effects of size, season and zone with data collected from Punta Allen and Vigía Chico during the 4 sampling seasons. In Model B, we tested the effects of the same factors as in Model A but with data collected from the 3 zones during the 2 closed seasons (CS1 and

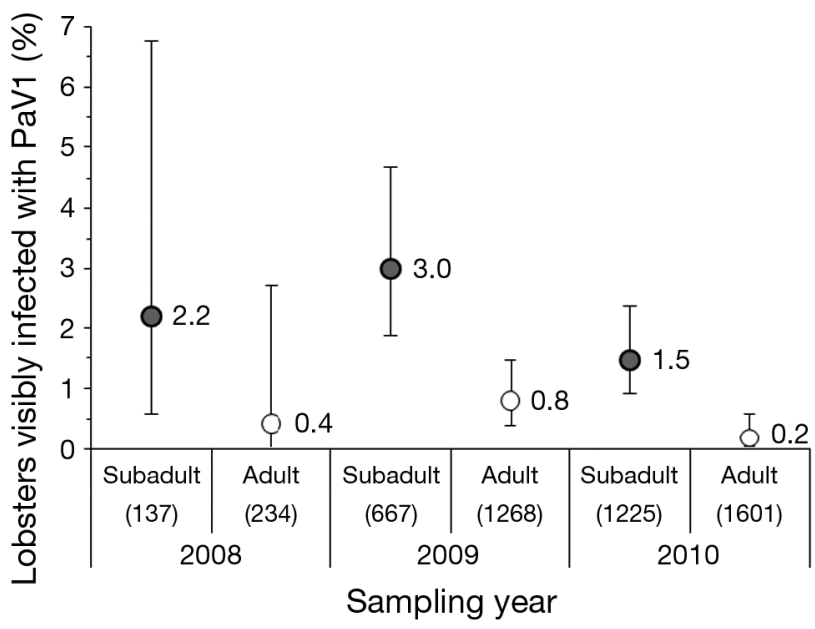

Fig. 2. Panulirus argus. Clinical prevalence of Panulirus argus virus 1 ( $\mathrm{PaV} 1$; percent of lobsters visibly infected) in subadult ( $\leq 80 \mathrm{~mm}$ carapace length, CL) and adult lobsters (>80 mm CL) sampled from the commercial catch in Bahía de la Ascensión at the onset of the 2008, 2009 and 2010 fishing seasons. Numbers in parentheses denote sample sizes. Error bars denote $95 \%$ CI

Table 2. Panulirus argus. Estimates for logistic regression analyses testing the effects of different factors on the probability of finding lobsters visibly infected with PaV1 in the commercial catch from Bahía de la Ascensión. Factors included in Model A were size (CL), year $(2008,2009,2010)$ and sex; 2010 and males are reference levels. Factors included in Model B were year and ontogenetic phase (subadults, adults); 2010 and adults are reference levels. In both models, interaction effects (not shown) were not significant

\begin{tabular}{|lcccccc|}
\hline Effect & Estimate & SE & Wald statistic & df & $p$ & Odds ratio (95\% CI) \\
\hline Model A & & & & & & \\
Size & -0.221 & 0.030 & 54.913 & 1 & $<0.001$ & $0.80(0.76-0.85)$ \\
2008 & -0.053 & 0.402 & 0.018 & 1 & 0.894 & $0.95(0.43-2.09)$ \\
2009 & 0.480 & 0.246 & 3.824 & 1 & 0.051 & $1.62(1.00-2.62)$ \\
Females & -0.303 & 0.221 & 1.881 & 1 & 0.170 & $0.74(0.48-1.18)$ \\
Model B & & & & 1 & 0.904 & $1.05(0.47-2.33)$ \\
2008 & -0.049 & 0.406 & 0.015 & 1 & $<0.001$ & $1.68(1.02-2.77)$ \\
2009 & 0.519 & 0.255 & 4.128 & 1 & $2.33(1.49-3.65)$ \\
Subadults & 0.847 & 0.229 & 13.683 & & & \\
\hline
\end{tabular}


Table 3. Panulirus argus. Numbers of spiny lobsters sampled from casitas in Bahía de la Ascensión (size range: 9.2 to $115.0 \mathrm{~mm} \mathrm{CL}$ ) and estimates of clinical prevalence of PaV1 (percent of lobsters visibly infected) by sampling season, zone and ontogenetic phase (small juveniles: $\leq 30 \mathrm{~mm} \mathrm{CL}$; large juveniles: 30.1 to $50 \mathrm{~mm} \mathrm{CL}$; subadults: 50.1 to $80 \mathrm{~mm} \mathrm{CL}$; adults: > $80 \mathrm{~mm} \mathrm{CL}$ )

\begin{tabular}{|lcccc|}
\hline Category & $\begin{array}{c}\text { Visibly } \\
\text { infected }\end{array}$ & $\begin{array}{c}\text { Grossly } \\
\text { normal }\end{array}$ & Total & $\begin{array}{c}\text { Clinical prevalence } \\
(\%) \text { of PaV1 (95\% CI) }\end{array}$ \\
Season & & & & \\
Fishing season 1 & 37 & 856 & 893 & $4.1(3.0-5.7)$ \\
Closed season 1 & 125 & 1962 & 2087 & $6.0(5.0-7.1)$ \\
Fishing season 2 & 27 & 530 & 557 & $4.8(3.3-7.1)$ \\
Closed season 2 & 58 & 1254 & 1312 & $4.4(3.4-5.7)$ \\
Zone & 155 & 1687 & 1842 & $8.4(7.3-9.9)$ \\
Punta Allen & 31 & 1985 & 2016 & $1.5(1.1-2.2)$ \\
Vigía Chico & 61 & 930 & 991 & $6.2(4.8-7.8)$ \\
Los Cayos & & & & \\
Ontogenetic phase & 52 & 397 & 449 & $11.6(8.8-15.0)$ \\
Small juveniles & 152 & 1399 & 1551 & $9.8(8.4-11.4)$ \\
Large juveniles & 43 & 2534 & 2577 & $1.7(1.3-2.3)$ \\
Subadults & 0 & 272 & 272 & $0(0-1.7)$ \\
Adults & & & & \\
\hline
\end{tabular}

CS1 (odds ratio: 3.08 ) relative to CS2 and was significantly higher in Punta Allen (odds ratio: 2.73) relative to Vigía Chico (Table 4). The lack of significant interactions ( $\mathrm{p}$-values: 0.150 to 0.324 ) reflected a similar seasonal pattern in clinical prevalence in these 2 zones (Fig. 3). Estimates for Model $B$ showed that the probability of finding clinically infected lobsters decreased with increasing lobster size, was higher in CS1 (odds ratio: 1.50) relative to CS2 and was significantly higher in Punta Allen (odds ratio: 2.13) and lower in Vigía Chico (odds ratio: 0.32) relative to Los Cayos (Table 4), with no significant interactions (p-values: 0.063 to 0.981). Estimates for Model $\mathrm{C}$ revealed that the probability of finding clinically infected lobsters was significantly higher in CS2). In Model C, we tested for the effects of ontogenetic phase (excluding adults) and zone after pooling the data from the 4 sampling seasons for each zone. Estimates for Model A showed that the probability of finding clinically infected lobsters decreased with increasing lobster size, was significantly lower in FS1 (odds ratio: 0.41) and higher in small juveniles (odds ratio: 2.25) and large juveniles (odds ratio: 1.60) relative to subadults, and significantly higher in Punta Allen (odds ratio: 1.57) and lower in Vigía Chico (odds ratio: 0.43) relative to Los Cayos (Table 4). The lack of significant interactions (p-values: 0.150 to 0.918 ) and the high degree of overlap in $95 \%$ CIs for the odds ratio corre-

Table 4. Panulirus argus. Estimates for logistic regression analyses testing the effects of different factors on the probability of finding lobsters visibly infected with PaV1 in samples taken directly from casitas. Factors included in Models A and B were size (CL), sampling season and zone. In Model A there were 4 levels for season (FS1, CS1, FS2, CS2) and 2 levels for zone (Punta Allen, Vigía Chico); CS2 and Vigía Chico are reference levels. In Model B there were 2 levels for season (CS1 and CS2) and 3 levels for zone (Punta Allen, Vigía Chico, Los Cayos); CS2 and Los Cayos are reference levels. Factors included in Model C were ontogenetic phase (3 levels, small juveniles: $\leq 30 \mathrm{~mm} \mathrm{CL}$; large juveniles: 30.1 to $50 \mathrm{~mm} \mathrm{CL}_{\text {; }}$ subadults: 50.1 to $80 \mathrm{~mm}$ CL) and zone (3 levels: Punta Allen, Vigía Chico, Los Cayos); subadults and Los Cayos are reference levels. In all models, interaction effects (data not shown) were not significant

\begin{tabular}{|c|c|c|c|c|c|c|}
\hline Effect & Estimate & SE & Wald statistic & df & $\mathrm{p}$ & Odds ratio $(95 \% \mathrm{CI})$ \\
\hline \multicolumn{7}{|l|}{ Model A } \\
\hline Size & -0.057 & 0.005 & 111.040 & 1 & $<0.001$ & $0.94(0.93-0.95)$ \\
\hline FS1 & -0.884 & 0.405 & 4.771 & 1 & 0.029 & $0.41(0.19-0.91)$ \\
\hline CS1 & 1.125 & 0.204 & 30.293 & 1 & $<0.001$ & $3.08(2.06-4.60)$ \\
\hline FS2 & -0.089 & 0.322 & 0.076 & 1 & 0.783 & $0.91(0.49-1.72)$ \\
\hline Punta Allen & 1.003 & 0.186 & 29.032 & 1 & $<0.001$ & $2.73(1.89-3.93)$ \\
\hline \multicolumn{7}{|l|}{ Model B } \\
\hline Size & -0.064 & 0.005 & 142.163 & 1 & $<0.001$ & $0.94(0.93-0.95)$ \\
\hline $\mathrm{CS} 1$ & 0.402 & 0.138 & 8.450 & 1 & 0.004 & $1.50(1.14-1.96)$ \\
\hline Punta Allen & 0.755 & 0.157 & 23.110 & 1 & $<0.001$ & $2.13(1.56-2.89)$ \\
\hline Vigía Chico & -1.154 & 0.255 & 20.528 & 1 & $<0.001$ & $0.32(0.19-0.52)$ \\
\hline \multicolumn{7}{|l|}{ Model C } \\
\hline Small juveniles & 0.809 & 0.141 & 33.051 & 1 & $<0.001$ & $2.25(1.70-2.96)$ \\
\hline Large juveniles & 0.472 & 0.110 & 18.414 & 1 & $<0.001$ & $1.60(1.29-1.99)$ \\
\hline Punta Allen & 0.451 & 0.108 & 17.382 & 1 & $<0.001$ & $1.57(1.27-1.94)$ \\
\hline Vigía Chico & -0.847 & 0.150 & 31.998 & 1 & $<0.001$ & $0.43(0.32-0.57)$ \\
\hline
\end{tabular}




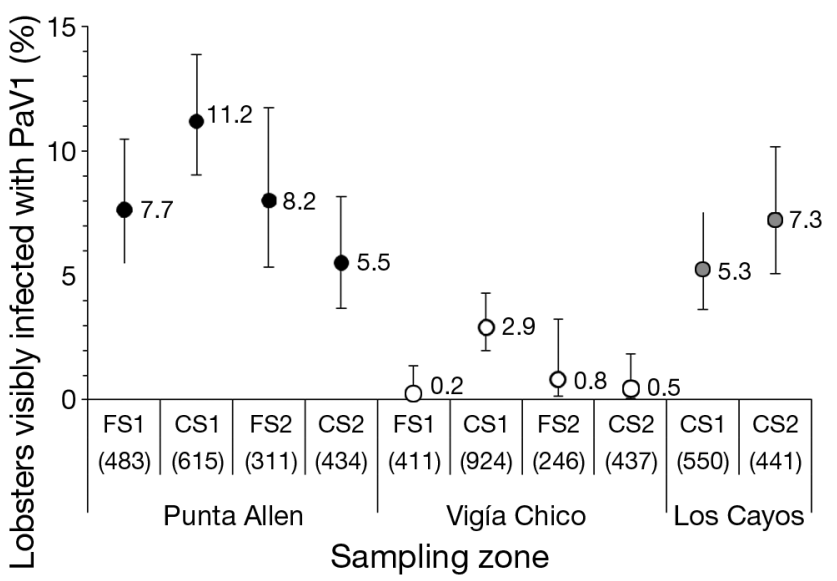

Fig. 3. Panulirus argus. Clinical prevalence of PaV1 (percent of lobsters visibly infected) in lobsters sampled directly from casitas in 3 bay zones (Punta Allen, Vigía Chico, Los Cayos) during 4 sampling seasons (FS1: fishing season 1, November 2008 to February 2009; CS1: closed season 1, May 2009; FS2: fishing season 2, December 2009 to February 2010; CS2: closed season 2, April 2010). Los Cayos was not sampled during FS1 and FS2. Numbers in parentheses are sample sizes. Error bars denote $95 \%$ CI

sponding to small and large juveniles (see Table 3) indicate that clinical prevalence of PaV1 was similar in lobsters of these 2 ontogenetic phases, but much higher than in subadults.

Clinical prevalence of PaV1 in subadult and adult lobsters did not differ significantly with provenance of samples, i.e. commercial catch (see Table 1) versus casitas (see Table 3$)(2 \times 2$ contingency table analyses; subadults: $\chi^{2}{ }_{1}=0.600, \mathrm{p}=0.438$; adults: $\chi^{2}{ }_{1}=$ $0.380, \mathrm{p}=0.537$ ).

\section{DISCUSSION}

Overall, our results suggest that the use of casitas to harvest lobsters commercially does not necessarily affect the clinical prevalence of PaV1 in Panulirus argus. For example, the average clinical prevalence in lobsters sampled from casitas in Bahía de la Ascensión $(4.8 \%)$ was similar to the average clinical prevalence estimated in the Gulf of Batabanó, Cuba $(4.7 \%)$, where casitas are also extensively used (Cruz-Quintana et al. 2011), and in Florida Bay, USA $(5 \%)$, where casitas are not used (Behringer et al. 2011), and clinical prevalence of PaV1 is significantly higher in lobsters $\leq 50 \mathrm{~mm}$ CL in all these locations. However, the magnitude of prevalence of pathogenic infections may vary in space and time owing to the effects of many intrinsic (e.g. nutritional condition, molting activity, changes in host immune defense factors) and extrinsic factors (e.g. habitat features, sea water temperature, salinity, rainfall) (Altizer et al. 2006, Shields et al. 2007, Mullowney et al. 2011). Thus, clinical prevalence of PaV1 ranged from 0 to $>40 \%$ in individual sites over Florida Bay sampled in different seasons (Behringer et al. 2011) and was higher during the rainy season than during the dry season in Cuba, where it also varied between sampling zones (Cruz-Quintana et al. 2011). In Bahía de la Ascensión, clinical prevalence of PaV1 varied with sampling season, but was consistently lower in Vigía Chico than in Punta Allen and Los Cayos. Interestingly, the true prevalence of PaV1 was also found to be significantly lower in Vigía Chico relative to Punta Allen, as revealed by PCR assays testing for the presence of PaV1 DNA in hundreds of lobsters from these 2 zones (J. P. Huchin-Mian unpubl. data). In conjunction, these findings suggest that the magnitude of the prevalence of PaV1 in the full size range of lobsters is not necessarily influenced by the use of casitas per se but partially depends on local environmental features.

Adult Panulirus argus can be infected with PaV1 (Huchin-Mian et al. 2009, Behringer et al. 2012) but are less likely to develop the disease than are smaller conspecifics. However, adult lobsters are the main target of the fisheries, but few studies have examined the clinical or true prevalence of PaV1 in wild adult lobsters (Behringer et al. 2011, 2012, Cruz-Quintana et al. 2011). In Bahía de la Ascension, none of the 272 adults that we sampled from casitas was clinically infected. However, as there are currently $\sim 18600$ casitas deployed throughout this bay (Sosa-Cordero et al. 2008), we were able to examine a total of 3103 adult lobsters from the commercial catch, of which $14(0.45 \%)$ were clinically infected. This estimate does not differ significantly from the clinical prevalence of PaV1 in adult lobsters sampled from casitas in Cuba in 2003 to 2004 $(0.95 \%, N=739)$ (Cruz-Quintana et al. 2011) $(2 \times 2$ contingency table, $\chi^{2}{ }_{1}=1.870, p=0.172$ ), but a comparison with locations where casitas are not used would be of more interest. In the Florida Keys, USA, where lobsters are caught by means of traps, clinical prevalence of PaV1 in adult lobsters was $0.25 \%(\mathrm{~N}=1531)$ in 2001 (Behringer et al. 2011) and $0 \%(\mathrm{~N}=151)$ in 2008 to 2009 (Behringer et al. 2012). These levels of clinical prevalence did not differ significantly from those found in Cuba and Bahía de la Ascensión $\left(2 \times 4\right.$ contingency table, $\chi^{2}{ }_{3}=$ 5.944, $\mathrm{p}=0.114)$. However, PCR assays revealed that many adult lobsters in the 2008 to 2009 samples 
from Florida were subclinically infected with PaV1 (Behringer et al. 2012), as were many lobsters of all sizes in the 2009 to 2010 samples from Bahía de la Ascensión (J. P. Huchin-Mian unpubl. data).

Over the last decade, the production of Panulirus argus has steadily declined throughout the Caribbean, both in trap-based fisheries (e.g. Florida and Honduras/Nicaragua) and in some casita-based fisheries (e.g. Cuba and the Bahamas) (Ehrhardt et al. 2010, Behringer et al. 2012). Whether PaV1 has played a role in this decline remains unknown, given the potentially confounding effects of multiple environmental, climatic, and anthropogenic factors on the population dynamics of exploited crustaceans (e.g. Bonami \& Zhang 2011, Stentiford \& Neil 2011). However, this declining trend has not occurred in Bahía de la Ascensión. On the contrary, the production of $P$. argus in this bay increased from an average of $29 \mathrm{t}$ of lobster tails per year ( $90 \mathrm{t}$ of whole lobsters) in the period from 1990 to 1999 (before emergence of the PaV1 disease) to an average of $40 \mathrm{t}$ per year $(\sim 120 \mathrm{t}$ of whole lobsters) in the period from 2000 to 2006 (after emergence of the disease), despite a substantial reduction in several fishing effort indicators (e.g. number of fishers, boats and casitas) between the 2 periods (Sosa-Cordero et al. 2008). These numbers represent an increase from 15.8 to $22.5 \%$ of the total lobster production of the state of Quintana Roo between the 2 periods, suggesting that, at least up to 2006, PaV1 had no discernible impact on the sustainability of the lobster fishery in Bahía de la Ascensión. In 2007, the fishing cooperative stopped commercializing legal-sized lobsters clinically infected with PaV1 despite the loss of revenue that this would entail, but the fishers continue extracting these lobsters from the casitas in order to destroy them on land. However, this operation cannot be performed during the closed season and, in addition, no sublegal-sized lobsters can be extracted from casitas at any time. Moreover, in Bahía de la Ascensión and elsewhere, many lobsters of all sizes that appear grossly normal have been found to be subclinically infected, and although some of these lobsters may never develop the disease, they may represent a background source of infection (Huchin-Mian et al. 2009, unpubl. data, Behringer et al. 2012). Therefore, in addition to determining which local factors are more likely to influence the susceptibility of hosts to PaV1, future research should also aim to estimate local mortality rates associated with PaV1 in lobsters from different ontogenetic phases.
Acknowledgements. We greatly appreciate the help in field work provided by J. P. Huchin-Mian, Á. Fuentes-Breña, T. Arrúa-Ortiz and M. Ley. We especially thank the members of the Sociedad Cooperativa 'Pescadores de Vigía Chico' for allowing us to sample thousands of lobsters and for providing logistic support. Funds for this study were provided by Consejo Nacional de Ciencia y Tecnología, México (project no. 82724-Q and graduate studentship no. 26243 for R.I.C.Z.) and Universidad Nacional Autónoma de México. Annual permits to sample lobsters from Bahía de la Ascensión were issued by Comisión Nacional de Acuacultura y Pesca, México.

\section{LITERATURE CITED}

Altizer S, Dobson A, Hosseini P, Hudson P, Pascual M, Rohani P (2006) Seasonality and the dynamics of infectious diseases. Ecol Lett 9:467-484

Arellano-Méndez LU, Liceaga-Correa MA, Herrera-Silveira JA, Hernández-Nuñez H (2011) Impacto por huracanes en las praderas de Thalassia testudinum (Hydrocharitaceae) en el Caribe Mexicano. Rev Biol Trop 59:385-401

Behringer DC, Butler MJ IV, Shields JD (2006) Avoidance of disease in social lobsters. Nature 441:421

Behringer DC, Butler MJ IV, Shields JD, Moss J (2011) Review of Panulirus argus virus 1 -a decade after its discovery. Dis Aquat Org 94:153-160

Behringer DC, Butler MJ IV, Moss J, Shields JD (2012) PaV1 infection in the Florida spiny lobster (Panulirus argus) fishery and its effects on trap function and disease transmission. Can J Fish Aquat Sci 69:136-144

> Bonami JR, Zhang S (2011) Viral diseases in commercially exploited crabs: a review. J Invertebr Pathol 106:6-17

> Briones-Fourzán P (1994) Variability in postlarval recruitment of the spiny lobster Panulirus argus (Latreille, 1804) to the Mexican Caribbean coast. Crustaceana 66:326-340

> Briones-Fourzán P, Lozano-Álvarez E (2001) Effects of artificial shelters (Casitas) on the abundance and biomass of juvenile spiny lobsters Panulirus argus in a habitat-limited tropical reef lagoon. Mar Ecol Prog Ser 221:221-232

Briones-Fourzán P, Lozano-Álvarez E, Eggleston DB (2000) The use of artificial shelters (Casitas) in research and harvesting of Caribbean spiny lobsters in Mexico. In: Phillips BF, Kittaka J (eds) Spiny lobsters: fisheries and culture, 2nd edn. Blackwell, Oxford, p 420-446

> Briones-Fourzán P, Lozano-Álvarez E, Negrete-Soto F, Barradas-Ortiz C (2007) Enhancement of juvenile Caribbean spiny lobsters: an evaluation of changes in multiple response variables with the addition of large artificial shelters. Oecologia 151:401-416

Butler MJ IV, Behringer DC, Shields JD (2008) Transmission of Panulirus argus virus 1 (PaV1) and its effect on the survival of juvenile Caribbean spiny lobster. Dis Aquat Org 79:173-182

Childress MJ, Herrnkind WF (1996) The ontogeny of social behaviour among juvenile Caribbean spiny lobsters. Anim Behav 51:675-687

Childress MJ, Herrnkind WF (2001) The guide-effect influence on the gregariousness of juvenile Caribbean spiny lobsters. Anim Behav 62:465-472

Cruz R, Phillips BF (2000) The artificial shelters (Pesqueros) used for the spiny lobster (Panulirus argus) fisheries in Cuba. In: Phillips BF, Kittaka J (eds) Spiny lobsters: fisheries and culture, 2nd edn. Blackwell, Oxford, p 400-419 
Cruz-Quintana Y, Rodríguez-Canul R, Vidal-Martínez VM (2011) First evidence of Panulirus argus Virus 1 (PaV1) in spiny lobster from Cuba and clinical estimation of its prevalence. Dis Aquat Org 93:141-147

Ehrhardt NM, Puga R, Butler MJ IV (2010) Large ecosystem dynamics and fishery management concepts: the Caribbean spiny lobster, Panulirus argus, fisheries. In: Fanning L, Mahon R, McConney P (eds) Towards marine ecosystem-based management in the wider Caribbean. Amsterdam University Press, Amsterdam, p 157-175

Flegel TW (2007) Update on viral accommodation, a model for host-viral interaction in shrimp and other arthropods. Dev Comp Immunol 31:217-231

> Flegel TW, Sritunyalucksana K (2011) Shrimp molecular responses to viral pathogens. Mar Biotechnol 13:587-607

- Herrnkind WF, Childress MJ, Lavalli KL (2001) Cooperative defence and other benefits among exposed spiny lobsters: inferences from group size and behaviour. Mar Freshw Res 52:1113-1124

Huchin-Mian JP, Rodríguez-Canul R, Arias-Bañuelos E, Simá-Álvarez R, Pérez-Vega JA, Briones-Fourzán P, Lozano-Álvarez E (2008) Presence of Panulirus argus Virus 1 (PaV1) in juvenile spiny lobsters Panulirus argus from the Caribbean coast of Mexico. Dis Aquat Org 79:153-156

> Huchin-Mian JP, Briones-Fourzán P, Simá-Álvarez R, CruzQuintana Y and others (2009) Detection of Panulirus argus Virus 1 (PaV1) in exported frozen tails of subadultadult Caribbean spiny lobsters Panulirus argus. Dis Aquat Org 86:159-162

Jordán-Dahlgren E, Martín-Chávez E, Sánchez-Segura M, González de la Parra A (1994) The Sian ka'an Biosphere Reserve coral reef system, Yucatan peninsula, Mexico. Atoll Res Bull 423:1-31

Li C, Shields JD, Small HJ, Reece KS, Hartwig CL, Cooper RA, Ratzlaff RE (2006) Detection of Panulirus argus Virus 1 (PaV1) in the Caribbean spiny lobster using fluorescence in situ hybridization (FISH). Dis Aquat Org 72 : 185-192

Lozano-Álvarez E，Briones-Fourzán P, Phillips BF (1991) Fishery characteristics, growth, and movements of the spiny lobster Panulirus argus in Bahía de la Ascensión, Mexico. Fish Bull 89:79-89

Lozano-Álvarez E， Briones-Fourzán P, Negrete-Soto F (1993) Occurrence and seasonal variations of spiny lobsters, Panulirus argus (Latreille), on the shelf outside Bahía de la Ascensión, Mexico. Fish Bull 91:808-815

Lozano-Álvarez E, Briones-Fourzán P, Ramírez-Estévez A,

Editorial responsibility: Grant Stentiford,

Weymouth, UK
Placencia-Sánchez D, Huchin-Mian JP, Rodríguez-Canul R (2008) Prevalence of Panulirus argus Virus 1 (PaV1) and habitation patterns of healthy and diseased Caribbean spiny lobsters in shelter-limited habitats. Dis Aquat Org 80:95-104

Montgomery-Fullerton MM, Cooper RA, Kauffman KM, Shields JD, Ratzlaff RE (2007) Detection of Panulirus argus Virus 1 in Caribbean spiny lobsters. Dis Aquat Org 76:1-6

Mullowney DR, Dawe EG, Morado JR, Cawthorn RJ (2011) Sources of variability in prevalence and distribution of bitter crab disease in snow crab (Chionoecetes opilio) along the northeast coast of Newfoundland. ICES J Mar Sci 68:463-471

Nevitt G, Pentcheff ND, Lohmann KJ, Zimmer RK (2000) Den selection by the spiny lobster Panulirus argus: testing attraction to conspecific odors in the field. Mar Ecol Prog Ser 203:225-231

Newcombe RG (1998) Two-sided confidence intervals for the single proportion: comparison of seven methods. Stat Med 17:857-872

Pascual-Jiménez C, Huchin-Mian JP, Simoes N, BrionesFourzán P and others (2012) Physiological and immunological characterization of Caribbean spiny lobsters Panulirus argus naturally infected with Panulirus argus virus (PaV1). Dis Aquat Org 100:113-124

Phillips BF, Melville-Smith R (2006) Panulirus species. In: Phillips BF (ed) Lobsters: biology, management, aquaculture and fisheries. Blackwell, Oxford, p 359-384

Ratchford SG, Eggleston DB (1998) Size- and scale-dependent chemical attraction contribute to an ontogenetic shift in sociality. Anim Behav 56:1027-1034

Shields JD (2011) Diseases of spiny lobsters: a review. J Invertebr Pathol 106:79-91

> Shields JD, Behringer DC (2004) A new pathogenic virus in the Caribbean spiny lobster Panulirus argus from the Florida Keys. Dis Aquat Org 59:109-118

Shields JD, Taylor DM, O'Keefe PG, Colbourne E, Hynick E (2007) Epidemiological determinants in outbreaks of bitter crab disease (Hematodinium sp.) in snow crabs Chionoecetes opilio from Conception Bay, Newfoundland, Canada. Dis Aquat Org 77:61-72

Sosa-Cordero E, Liceaga-Correa MLA, Seijo JC (2008) The Punta Allen lobster fishery: current status and recent trends. In: Townsend R, Uchida H (eds) Case studies in fisheries self-governance. FAO Fish Tech Paper 504. FAO, Rome, p 149-162

> Stentiford GD, Neil DN (2011) Diseases of Nephrops and Metanephrops: a review. J Invertebr Pathol 106:92-109

Submitted: August 29, 2011; Accepted: February 8, 2012

Proofs received from author(s): April 20, 2012 